\title{
Autophagic Dysfunction in Type 2 Diabetes Mellitus: Pathophysiology and Therapeutic Implications
}

\author{
Md. Tanjir Islam ${ }^{1}$, Md. Sahab Uddin ${ }^{1 *}$, Kamrun Nahar Lucky ${ }^{1}$, Md. Manjurul Islam² ${ }^{2}$ Sheik Md. Saiful Islam ${ }^{3}$, Md. Tanvir Kabir $^{4}$, Md. Farhad Hossain $^{5}$, Abdullah \\ Al Mamun ${ }^{1}$ and Md. Shah Amran ${ }^{6}$ \\ ${ }^{1}$ Department of Pharmacy, Southeast University, Dhaka, Bangladesh \\ ${ }^{2}$ Department of Pharmacy, University of Development Alternative, Dhaka, Bangladesh \\ ${ }^{3}$ Department of Pharmacy, State University of Bangladesh, Dhaka, Bangladesh \\ ${ }^{4}$ Department of Pharmacy, BRAC University, Dhaka, Bangladesh \\ ${ }^{5}$ Department of Physical Therapy, Graduate School of Inje University, Gimhae, Korea \\ ${ }^{6}$ Department of Pharmaceutical Chemistry, Faculty of Pharmacy, University of Dhaka, Dhaka, Bangladesh
}

*Corresponding author: Md. Sahab Uddin, Department of Pharmacy, Southeast University, Dhaka, Bangladesh, Tel: +880 1710220110, 1670760546; E-mail: msu-neuropharma@hotmail.com; msu_neuropharma@hotmail.com

Received date: March 29, 2017; Accepted date: May 19, 2017; Published date: May 25, 2017

Copyright: () 2017 Islam MT, et al. This is an open-access article distributed under the terms of the Creative Commons Attribution License, which permits unrestricted use, distribution, and reproduction in any medium, provided the original author and source are credited.

\begin{abstract}
Autophagy is an intracellular catabolic system by which cells degrade and recycle cytoplasmic constituents such as organelles and proteins through the lysosome-dependent path. Belgian biochemist, Christian de Duve coined the name "autophagy" in 1963. The identification of autophagy-related genes and finally discoveries of mechanisms for autophagy led to the award of the 2016 Nobel Prize in Medicine or Physiology to Japanese cell biologist, Yoshinori Ohsumi specializing in autophagy. Autophagy shows a crucial role in removing aggregated proteins and damaged organelles in order to conserve intracellular homeostasis. In order to control cellular homeostasis and disease states autophagy illustrates a vital role. For insulin resistant patients, insulin secretion and the mass of pancreatic $\beta$-cells is increased on account of alterations in the expression and activities of numerous proteins in $\beta$-cells. Simultaneously, autophagic activity seems to also be upgraded to adjust to the dynamic changes taking place in $\beta$-cells. Actually, faulty autophagy in $\beta$-cells recaps a number of features that are perceived in pancreatic islets in the course of the formation of type 2 diabetes mellitus (T2DM). In contrast, the dyregulation of autophagic function is also appears to happen in the $\beta$-cells of T2DM patients. Furthermore, autophagy deficiency is linked with the diabetes-related organ dysfunction. Therefore the intention of this study was to provide the impacts of autophagy based on current researches in the development of T2DM and to explore new therapeutic strategies for stopping T2DM pathogenesis.
\end{abstract}

Keywords: Autophagy; Cellular homeostasis; Type 2 diabetes mellitus; Pancreatic islets; $\beta$-cell

Abbreviations: ER: Endoplasmic Reticulum; mTOR: Mechanistic Target of Rapamycin; T2DM: Type 2 Diabetes Mellitus; S6K1: Ribosomal S6 Kinase 1; Ulk1: Unc-51-like Kinase; FIP200: 200 kDa FAK- Family Interacting Protein; LC3: Light Chain 3; Atg $7 \beta$ cell: $\beta$-Cell Specific Atg7-Knockout; GLP-1: Glucagon-like Peptide-1; UPR: Unfolded Protein Response; $o b / o b$ : Obese; IAPP: Islet Amyloid Polypeptide; PERK: Protein Kinase RNA-like ER Kinase; AB: Autophagic body; V: Vacuole; hIAPP: Human IAPP; IL-1 $\beta$ : Interleukin-1 $\beta$; PE: Phosphatidylethanolamine; NLRP3: Pyrin Domain-containing 3; NEFA: Nonesterified Fatty Acids; LAMP2: Lysosomal Associated Membrane Protein 2; AMPK: AMP-activated Protein Kinase.

\section{Introduction}

Autophagy is a process in which cellular components are orderly degraded and recycled to generate energy, cellular components and or build new cells [1]. The autophagy process starts to incorporate a portion of its own cellular constituents and transports it to the lytic compartment (i.e., lysosome) for reuse when cells face hostile conditions like nutrient depletion [1]. Autophagy is a Greek term which means self-eating [1]. Autophagy is initiated by nutritional deprivation to promote cell survival and to increase amino acid retrieval [2]. In addition, autophagy can control other essential cellular processes such as programmed cell death (e.g., apoptosis), inflammation, adaptive immune mechanisms, etc. [3].

Autophagy may promote cell death through degradation of cellular constituents and protect cells from cell death by providing essential nutrients and removing damaged organelles during cellular stress depending on the cellular and environmental context [4]. In the development and the maintenance of physiological function of normal tissues by degrading unnecessary or dysfunctional organelles such as mitochondria and rejuvenates their function, autophagy plays important roles [1,4].

Autophagy is an important parameter for various cellular functions and if this process fails than disruption or accumulation of abnormal mitochondria in adult tissues can occur $[5,6]$. Not only to the physiological roles has may autophagy also played pathogenic roles in diverse disease processes. Autophagy specific tissues may induce neurodegeneration or cardiomyopathy, particularly when cellular stress is increased, which is probably due to the accumulation of damaged molecules and organelles [7,8]. Some other studies have shown important roles for autophagy in eradication of microbes, 
Citation: Islam MT, Uddin MS, Lucky KN, Islam MM, Saiful Islam SM, et al. (2017) Autophagic Dysfunction in Type 2 Diabetes Mellitus:

Page 2 of 8

antigen presentation, and tumor suppression [9]. Autophagy also responsible for endoplasmic reticulum (ER) stresses responses [10].

Type 2 diabetes mellitus (T2DM) is known by abnormal regulation of nutrients and their metabolites that develop as a consequence of combined insulin resistance and relative insulin deficiency. Some downstream molecules of insulin like such as mechanistic target of rapamycin (mTOR) or ribosomal S6 kinase 1 (S6K1) are responsible to inhibit the process of autophagy [11]. It is found out that glucagon, a counter regulatory hormone of insulin, induces autophagy [12]. Because T2DM critically depends on the metabolism of nutrients, insulin action and its counter regulation, dysregulated autophagy may play a role in the pathogenesis of T2DM. Organelles like mitochondria and ER play important roles in $\beta$ cell survival, death, insulin secretion and insulin action, or sensitivity depends on autophagy for appropriate function $[13,14]$.

These kinds of findings indicate the possibility that autophagy is involved in diabetes by controlling hormone action and organelle function. But the exact relationship between autophagy and diabetes has been hardly studied, partly because of lack of proper animal models [15]. Autophagy could be a key regulator of cellular organelles in $\beta$ cells, where vigorous protein synthesis occurs, abundant energy is required and therefore function of ER and mitochondria may be critical, particularly when increased demand for insulin production exists such as insulin resistance [15]. Japanese cell biologist, Yoshinori Ohsumi has won the Nobel Prize in medicine or physiology because of his outstanding discoveries of mechanisms of autophagy in 2016. In this consequence the purpose of this study was to give the relationship of autophagy and the pathogenesis of T2DM as well as autophagytargeted therapeutic consequences.

\section{Autophagy and its Machinery}

The identification of autophagy-related genes and finally discoveries of mechanisms for autophagy contributed to the award of the 2016 Nobel Prize in Medicine or Physiology to Japanese cell biologist, Yoshinori Ohsumi specializing in autophagy. As stated earlier that autophagy, is a cellular degradation process that is involved in the clearance of long-lived proteins and organelles [16,17].

In living cell body autophagy has two major roles [18]. One is to recycle intracellular energy resources in response to conditions of nutrient depletion and another is to remove cytotoxic proteins and organelles under stressful conditions [19]. There are many types of autophagy have been found out in cells. They are macroautophagy, microautophagy and chaperone-mediated autophagy, all of which differ in mechanisms and functions. Macroautophagy is the most prevalent and hereafter is referred to as autophagy.

Autophagy is a complex process where initially de novo isolation membranes elongate and fuse while engulfing a portion of the cytoplasm within double-membrane vesicles [20]. There are many sources through which autophagosomes can originate and this may ER, mitochondria and even plasma membrane. Four major steps are involved in the formation of autophagosomes: initiation, nucleation, elongation and closure are represented in Figure 1.

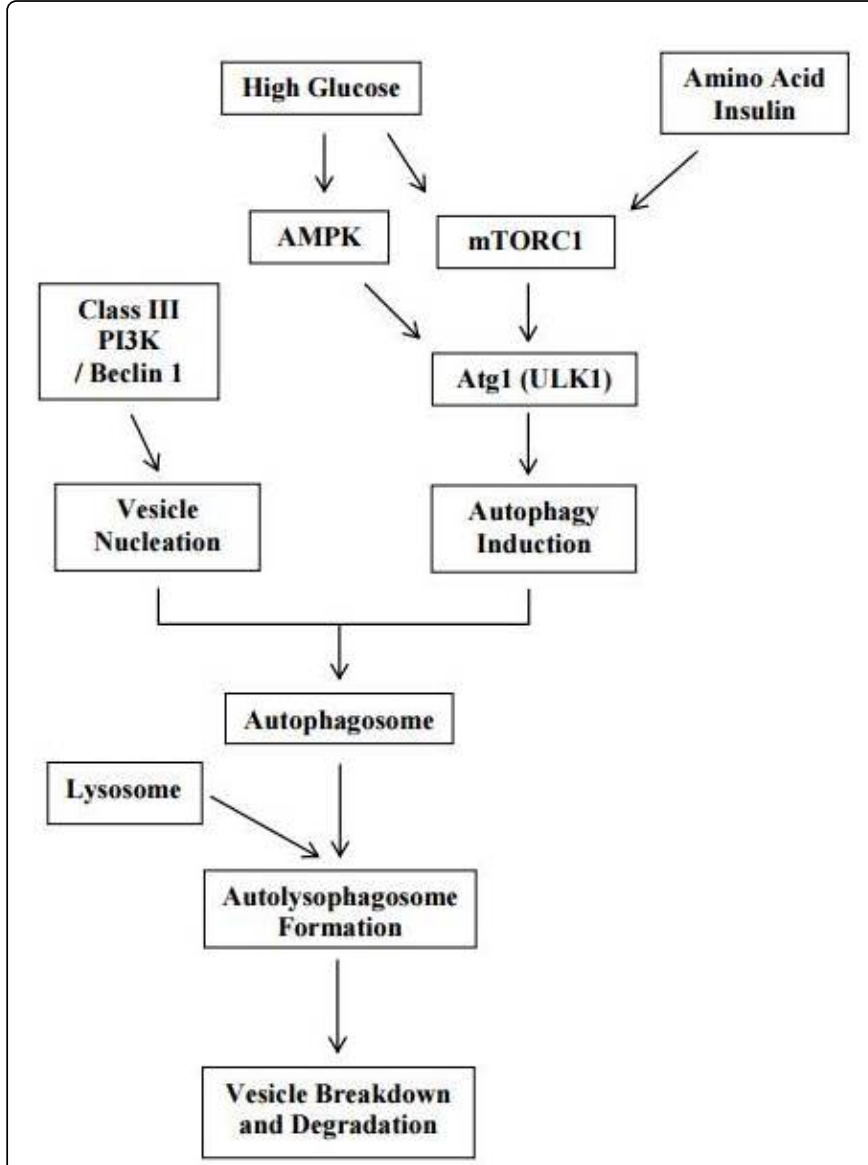

Figure 1: Steps of the autophagic pathways. Nucleation of an isolated membrane, or phagophore is accountable for the initiation of autophagy. The elongation of phagophore and its closes cases to form an autophagosome. The fusion of an autophagosome with a lysosome forms an autolysosome, wherein the acid hydrolases in the lysosome (i.e., cathepsin B and cathepsin L) breaking down the internal membrane as well as cytoplasmic contents. Initiation of autophagy is positively controlled by ULK1 and beclin-1, that is also positively controlled by AMP-activated protein kinase (AMPK) and blocked by mTORC1.

Every step involves autophagy-related proteins. Chemicals like unc-51-like kinase (Ulk1) complex, the mammalian ortholog of the yeast autophagy-related (Atg) 1 complex are initiated by autophagy. Ulk1 Ser/Thr protein kinase, Atg13 and $200 \mathrm{kDa}$ FAK-family interacting protein (FIP200), the mammalian homolog of the yeast Atg 17 protein, these all components are responsible for the formation of Ulk1 complex. Components like phosphorylation of Atg13 and FIP200 is essential for triggering autophagy. Phagophore nucleation is dependent on beclin 1, an hVps34 that consists of hVps34, hVps15, beclin 1 and Atg14 [21].

Two dependent ubiquitin-like conjugation systems: Atg12 and light chain 3 (LC3) are responsible for autophagosomes elongation and closure. The Atg12-Atg5 conjugates contribute to the stimulation and localization of the LC3 conjugation reaction. Isoform of LC3 is conjugated to phosphatidylethanolamine through two consecutive ubiquitination-like reactions catalyzed by the E1-like enzyme Atg7 and 
Citation: Islam MT, Uddin MS, Lucky KN, Islam MM, Saiful Islam SM, et al. (2017) Autophagic Dysfunction in Type 2 Diabetes Mellitus: Pathophysiology and Therapeutic Implications. J Diabeteas Metab 8: 742. doi:10.4172/2155-6156.1000742

Page 3 of 8

the E2-like enzyme Atg3, forming LC3-phosphatidylethanolamine conjugate (LC3-II). LC3-II is identified as a marker of the presence of autophagosomes in cell and animal experiments [22]. Autophagosomes may merge with the lysosomal compartment to form autolysosomes. The protein p62 localizes to autophagosomes by interacting with LC3 $[21,22]$. In the various studies accumulation of p62 has been observed in autophagy-deficient cells. Autophagic body is the inner membrane-bound structure of the autophagosome that is released into the vacuolar lumen by fusion of the autophagosomal outer membrane with the vacuolar membrane. In Figure 2, electron microscopic examination of morphology of vacuoles in multiple protease-deficient yeast (Saccharomyces cerevisiae) cells under nitrogen-starvation is presented [22].

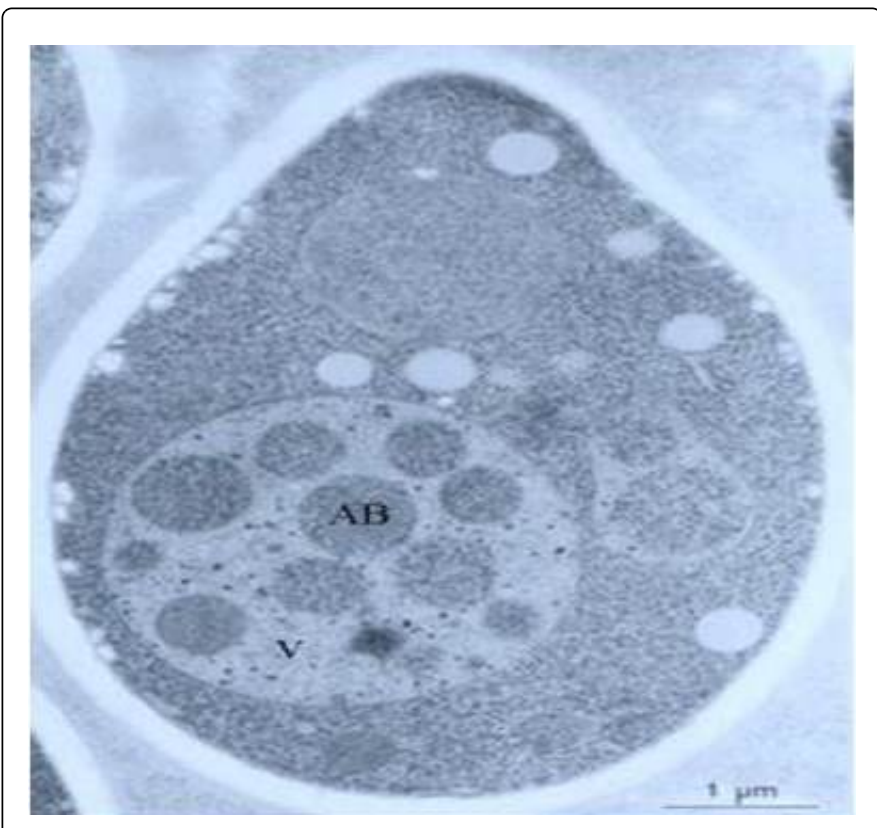

Figure 2: Microscopic examination of authophagic body inside protease-deficient yeast cell's vacuoles under nitrogen-starvation. Here, AB: Autophagic body; V: Vacuole [23].

\section{Impact of Autophagy in Pancreatic $\beta$ Cell}

Gene knockout technology in pancreatic $\beta$ cell has been used in some studies to find out the role of autophagy in body metabolism, but studies on the relationship between islet hormones and autophagy date back to much earlier days of autophagy research. Various scientific works on pancreatic islet hormones on autophagy started in the earlier age. One of the notable scientists, Christian de Duve received the Nobel Prize as he discovered lysosomes and he actually named the term 'autophagy' [16,17].

The phenomenon of autophagy was first observed in a glucagonperfused rat liver [12]. The role of autophagy in $\beta$ cell functioning was first recommended in paper presenting that $\beta$ cell that secretes hormone such as insulin are degraded by lysosomal enzymes in a process of crinophagy or autophagy [24]. In case of insulinoma cells the role of autophagy in the removal of mitochondria has also been found out [25]. As in recent time the mechanism of autophagy has become illuminated gradually recent studies on autophagy were conducted employing genetic technologies. $\beta$ cell specific Atg7- knockout $($ Atg $7 \Delta \beta$ cell $)$ mice were generated to investigate the role of $\beta$

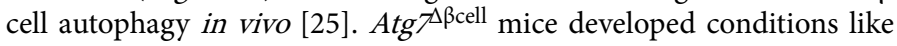
hyperglycemia and hypoinsulinemia, but not diabetes. Cellular degeneration and reduced $\beta$ cell mass were seen in this condition. Consumption of ubiquitin and p62 were seen which are some specific substrates of autophagy [26].

Not only morphological changes some other functional changes were also observed. In islets of mice $A \operatorname{tg} 7^{\Delta \beta \text { cell }}$ reduced insulin secretion and $\mathrm{Ca}^{2+}$ transients after glucose challenge were observed. In this regard, a glucagon-like peptide- 1 receptor agonist exendin-4, increased insulin release from autophagy deficient $\beta$ cells and decreased $\beta$ cell apoptosis and induction of the insulin secretory machinery. Another glucagon-like peptide-1 (GLP-1) receptor agonist up regulated autophagy levels in insulinoma cells [27]. Mechanism of autophagy by receptor agonists like GLP-1 might explain amelioration of ER stress in $\beta$ cells by exendin-4 [28]. Autophagy support ER stress response as found out by some studies. Receptor agonist GLP-1 may initiate autophagy in various tissues in body [29]. But yet now the mechanism linking GLP-1 receptor and autophagy is unclear.

\section{Autophagy on $\beta$ Cell and Diabetes}

Not only studies carry out to identify role of autophagy in $\beta$ cell physiology, the role of $\beta$ cell autophagy in the pathogenesis of diabetes has been studied. Studies find out that the formation of protein aggregates in pancreatic $\beta$ cells during hyperglycemia due to aggregate by autophagy [30]. Studies focused on ER stress and the ER stress response or the unfolded protein response (UPR) to understand the impact of $\beta$ cell autophagy on diabetes because ER distension was observed in autophagy deficient $\beta$ cells and ER stress is important for $\beta$ cell failure in T2DM [31]. To control unfolded proteins autophagy may also play a part [32].

During studied in autophagy deficient $\beta$ cells using real-timepolymerase chain reaction, significantly decreased expression of almost all UPR genes was observed. This was happened due to UPR gene expressions were upregulated by ER stress [18]. It was also noted ER stress is an adaptive response to ER stress. Deficient UPR in the presence of ER stress could represent a decompensated state. A recent study has shown that, when autophagy-deficient $\beta$ cells were treated with thapsigargin, cell death was more pronounced compared to autophagy-competent $\beta$ cells [19]. Because thapsigargin is a pharmacological ER stressor, free fatty acids which are more physiological ER stressors. When islet cells from $A \operatorname{tg} 7^{\Delta \beta \text { cell }}$ mice were treated with palmitic acid, cell death was again more pronounced [20]. These findings indicate that autophagy appears to be important for appropriate UPR in response to ER stress. Susceptibility of autophagydeficient $\beta$ cells to ER stressors was studied by breeding Atg $7 \Delta \beta$ cell mice to $o b / w$ mice carrying a heterozygous leptin gene mutation as obesity imposes ER stress on $\beta$ cells [21]. UPR gene expression was increased in the islets of obese $(o b / o b)$ mice, and such UPR gene induction was reduced in islets of $A \operatorname{tg} 7 \Delta \beta$ cell_-ob/ob mice, proposing that the demand for UPR, an adaptive reply in contrast to ER stress enforced by obesity, is unmet in autophagy-deficient $\beta$ cells are given in Figure 3 . Atg $7 \Delta$ cell $-o b / o b$ mice developed severe diabetes accompanied by an increased number of apoptotic $\beta$ cells, decreased $\beta$ cell mass and impaired $\beta$ cell function. These data demonstrate that $\operatorname{Atg} 7 \Delta \beta$ cell mice have defects in the adaptive increase in $\beta$ cell mass after high-fat diet [14]. 
Citation: Islam MT, Uddin MS, Lucky KN, Islam MM, Saiful Islam SM, et al. (2017) Autophagic Dysfunction in Type 2 Diabetes Mellitus: Pathophysiology and Therapeutic Implications. J Diabeteas Metab 8: 742. doi:10.4172/2155-6156.1000742

Page 4 of 8

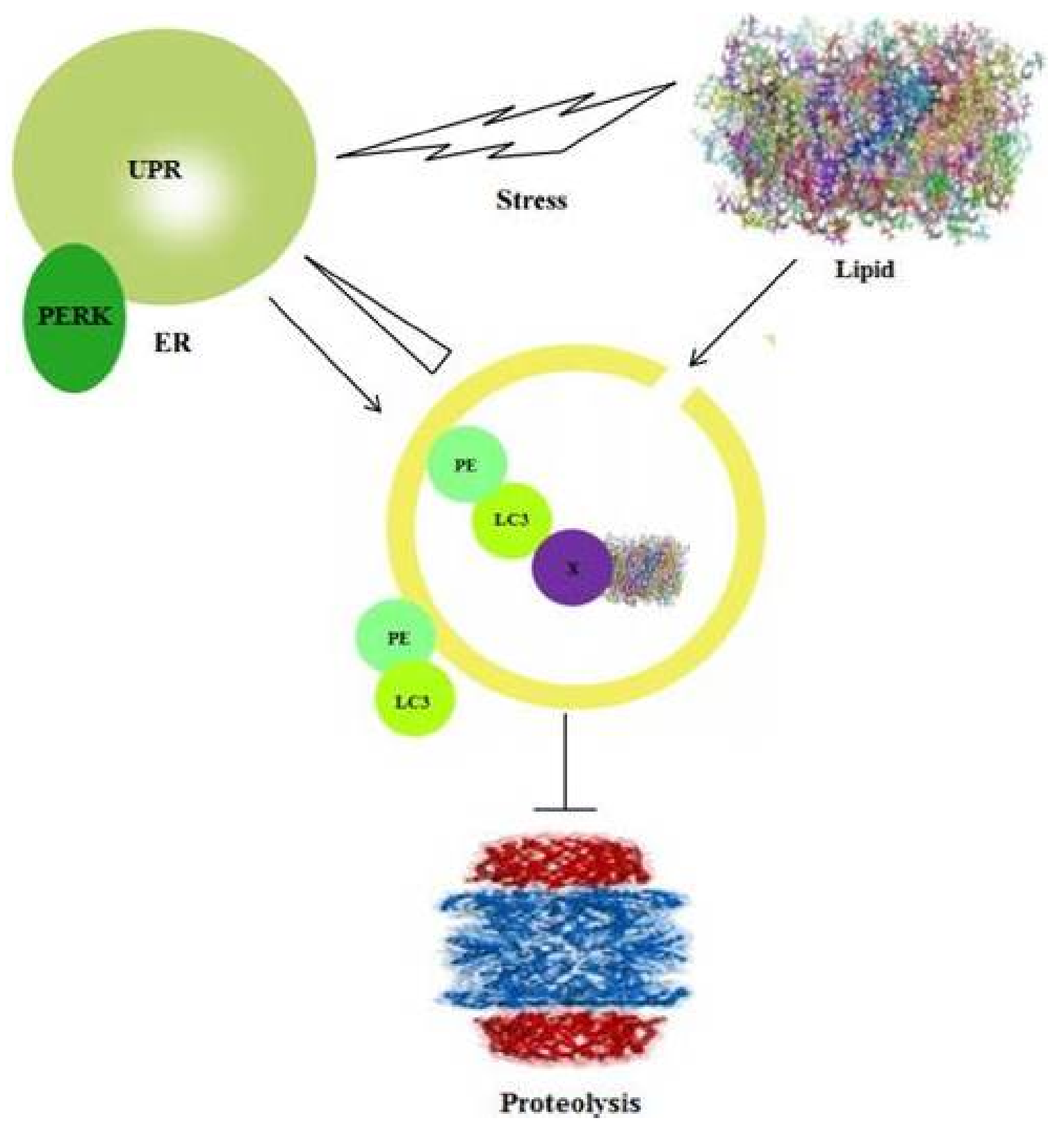

Figure 3: Connection between lipid, ER stress, UPR and autophagy in $\beta$ cells. Lipid injury or obesity cases ER stress and brings UPR as an adaptation to ER stress. Obesity also cases activation of autophagy (i.e., presented as a double-membrane structure in the figure, representing the autophagosome) to dispose of excess lipid by lipophagy. Unidentified autophagy receptor or adaptor (i.e., marked as ' $\mathrm{X}$ ') may play a part in 'lipophagy'. Activation of autophagy seems to support proper UPR (i.e., long triangle) owing to lipid injury or obesity since deficiency of autophagy compromises the UPR response in $\beta$-cells of pancreas. In contrast, ER stress response or UPR activates autophagy (i.e., arrow) by multiple mechanisms for example protein kinase RNA-like ER kinase (PERK). Consequently, UPR and activation of autophagy seem to act combinely in an interdependent way to lessen accumulation of excess lipid as well as lipid injury. Even though autophagy is increased by lipid overload or obesity, proteolysis may be decreased due to sequestration of autophagic machinery to 'lipophagy' [17].

These data are consistent with results from other papers reporting the protective role of autophagy against ER stress in $\beta$ cells [22]. Effects of drugs like rosiglitazone and metformin against lipoapoptosis of $\beta$ cells have also been important to autophagy enhancement through AMPK activation. Activation of autophagy was reported to protect insulinoma cells against glucotoxicity [3,22]. Inhibition of autophagy has been shown to reduce $\beta$ cell death due to knockdown of pancreatic and duodenal homeobox 1 while the significance of autophagic death has been debated [23]. Impairment of $\beta$ cell function and viability by rapamycin has also been attributed to over-induction of autophagy [33]. In role of $\beta$ cell autophagy in human diabetes has also been studied. There is seen an increase in autophagosome numbers which was observed in the islets of T2DM patients [34]. Increased autophagosome number representing increased autophagy level can be 
due to either enhanced autophagic activity or blockade of autophagy at the lysosomal step [1]. But it is not find out autophagic activity is increased in the islets of T2DM patients. Metformin a popular antidiabetic drug reduced accumulation of autophagic vacuoles in $\beta$ cells [34].

\section{Effect of Autophagy in Inflammation of Pancreatic Islets}

Islet amyloid polypeptide (IAPP) is a 37 residue peptide hormone released from $\beta$ cells. Membrane damage by human IAPP (hIAPP) oligomer is the main mechanism of hIAPP-induced $\beta$ cell injury. A membrane pore causing ion leakage caused by hIAPP oligomer may be inserted into the phospholipid membrane [35]. Furthermore, there is mechanism responsible for $\beta$ cell damage by hIAPP oligomer. In the pathogenesis of T2DM, inflammation plays as important factor [36]. The nucleotide-binding of oligomerization domain-like receptor family member, pyrin domain-containing 3 (NLRP3) has been playing an important role in $\beta$ cell failure of T2DM and in case of insulin resistance [37]. An important part of the inflammasome complex is NLRP, which is responsible for the activation of interleukin-1 $\beta$ (IL-1 $\beta$ ).

Studies found out that hIAPP, but not non-amyloidogenic rat IAPP, can activate NLRP3 inflammasomes [38]. So due to accumulation of hIAPP in islet, the inflammation would contribute to $\beta$ cell failure in human T2DM associated with islet amyloid deposition. Correspondingly autophagy deficiency is not a disease, but is a proinflammatory condition caused by increased inflammasome activation [39]. As $\beta$ cell autophagy might not directly affect inflammasome activation because $\beta$ cells cannot produce huge amounts of IL-1 $\beta$. Also, various factors like aging, genetic predisposition, or obesity would affect hIAPP-induced inflammasome activation and $\beta$ cell and $\beta$ cell dysfunction by influencing autophagy of macrophages, the main producers of IL- $1 \beta$ and these responsible for autophagy alternation.

\section{Autophagy and Insulin Resistance}

$\beta$-cell dysfunction as well as dysregulated autophagy may possibly be linked to insulin resistance because ER stress has been concerned not only in $\beta$-cell defect but also in insulin resistance [40]. Since autophagy deficiency could lead to irregular ER stress or ER stress response, diminished autophagy may affect insulin resistance. A study reported that autophagy deficiencies in the liver of obese mice and overexpression of $\mathrm{Atg} 7$ restored insulin sensitivity in conjunction with elevated expression of ER stress markers [41]. However, it is still debated whether ER stress is a cause of insulin resistance or only related to insulin resistance. In recent times, autophagy was stated to contribute to the down-regulation of insulin receptors and ER stressmediated insulin resistance as an adaptive process in ER stresses [42]. On the other hand, insulin resistance has been stated to suppress autophagy [43]. Even though these findings propose that autophagy may be linked to insulin resistance, straight causal connection between them would require more research.

\section{Roles of Autophagy on Diabetes and Diabetes-Related Organ Dysfunction}

Not only diabetic, autophagy is responsible for various cardiac diseases (Table 1). A recent research of autophagy on mice has shown that acute cardiac dysfunction arise when deletion of the Atg5 gene
[44]. From this type of research it has become clear that the deficiency in autophagy contributes to the progression of the multiple disease state. Another interesting report showed that autophagy has significant roles in the formation of obesity and insulin resistance in T2DM patients. The main factors of T2DM are obesity and insulin resistance. In our body only pancreatic $\beta$ cells responsible to control insulin resistance and maintain blood glucose level $[8,44,45]$. But the matter of fact is that this $\beta$ cells has a limited capacity to proliferate. Also apoptosis occurs in $\beta$-cell in the end phase of diabetes, leading to less insulin secretion and severe hyperglycemia.

At every step in the development of DM, autophagy has significant impact. Some factors which are responsible to $\beta$-cell apoptosis during the latter phase of diabetes development such as for glucotoxicity, free fatty acid-related lipotoxicity and ER stress [45]. The deletion of the Atg7 gene, enhances high-fat-diet-induced $\beta$-cell apoptosis and subsequent insufficient $\beta$-cell mass, leading to glucose intolerance resulting deficiency in pancreatic $\beta$-cell-specific autophagy $[46,47]$. All this suggests that autophagy plays a critical role in responses of $\beta$ cells to insulin resistance induced by a high-fat diet [47]. By this way autophagy in pancreatic $\beta$ cells plays a protective and antidiabetic role, similar to its roles in diabetic complications.

Another research which is conducted on mice has shown that liver, skeletal muscle and adipose tissue specific autophagy deficient mice are highly resistant to high-fat-diet-induced obesity and subsequent insulin resistance (Table 1) $[48,49]$. It is proved that autophagy is essential for lipid storage in species such as Caenorhabditis elegans [50]. As autophagy activated due to nutrient depletion, these findings may indicate that autophagy also is used to store sources of energy to cope with long-term starvation.

\begin{tabular}{|c|c|c|}
\hline Organ & Atg Gene & Effect \\
\hline \multicolumn{3}{|c|}{ Insulin-Sensitive Organ } \\
\hline Adipocyte & $\begin{array}{l}\text { Atg5 deletion } \\
\text { Atg7 deletion }\end{array}$ & $\begin{array}{l}\text { Anti-obesity } \\
\text { Insulin sensitization } \\
\text { Increased brown adipose tissue }\end{array}$ \\
\hline Liver & Atg7 deletion & $\begin{array}{l}\text { Anti-obesity } \\
\text { Insulin sensitization } \\
\text { Anti-hepatic steatosis }\end{array}$ \\
\hline Skeletal Muscle & Atg7 deletion & $\begin{array}{l}\text { Anti-obesity } \\
\text { Insulin sensitization } \\
\text { Increased lipolysis }\end{array}$ \\
\hline \multicolumn{3}{|c|}{ Damaged Organs } \\
\hline$\beta$-Cells & Atg7 deletion & $\begin{array}{l}\text { Degeneration of islet } \\
\text { Reduced insulin secretion } \\
\text { Glucose intolerance }\end{array}$ \\
\hline Heart & Atg 5 deletion & $\begin{array}{l}\text { Cardiac hypertrophy } \\
\text { Left ventricular dilatation } \\
\text { Contractile dysfunction }\end{array}$ \\
\hline Kidney & $\begin{array}{l}\text { Atg } 5 \text { deletion } \\
\text { Atg deletion }\end{array}$ & $\begin{array}{l}\text { Increased apoptosis } \\
\text { Undetermined }\end{array}$ \\
\hline
\end{tabular}

Table 1: Effects of autophagy deficiency in the development of organ dysfunction associated with diabetes [51].

Autophagy should be an effective medium to prevent obesity and insulin resistance. In fact, higher level of autophagy is required to protect organs once patients become insulin resistant and diabetic. 
Page 6 of 8

Consequently, relationship among autophagy, diabetes and complications of the latter are now becoming more complex. So the role of autophagy in the pathogenesis of both diabetes and diabetic created complications are needed to determine whether regulation of autophagy is important with diabetic complication in other organs.

\section{Therapeutic Activities to Activate Autophagy}

Autophagy activation has been found to be essential for calorie restriction mediated life span elongation and anti-aging effects in lower species [52] and perhaps even in mammals $[53,54]$. In case of T1D patients after islet transplantation, agent like rapamycin influences autophagy to suppress allograft rejection [55]. Other aspects of cellular functions are affected by rapamycin and it is quite impossible to predict the potentiality of rapamycin or related compounds as therapeutic agents in diabetes. Rapamycin may process potential role in T2DM by enhancing glucose intolerance in animals those fed a high-fat diet supplemented with branched chain amino acids but not those fed a high-fat diet alone, reported in a recent research [56]. Recently, various modulators of autophagy are developed and tested, which will optimistically lead to novel therapeutic opportunities relating diabetes, [57] other medical situations, etc. Metformin is a popular and most effective antidiabetic agent that reduces hepatic glucose output and enhances peripheral insulin sensitivity. T2DM patient's metformin decreases autophagic vesicle accretion and $\beta$ cell death in case of $\beta$ cells from T2DM patients and $\beta$ cells from nondiabetic controls exposed to nonesterified fatty acids (NEFA). This type of biological effect can be linked with restored lysosomal associated membrane protein 2 (LAMP2) expressions [58]. In diabetes patients under high concentrations of NEFA, LAMP2 expression is reduced. mTOR is inhibited by AMPK which is activated by metformin [59].

Furthermore this antidiabetic drug (i.e., metformin) may inhibit mTOR independent of AMPK [60]. This is reported that metformin is responsible for elimination of autophagic vesicles by the inhibition of mTOR. So a possible link between LAMP2 and AMPK activity has been suggested, but it requires evidence. In case of prediabetes and or at the initial stages of the disease, metformin has some contribution on preserving islet structure and $\beta$ cell mass. But this is still pending clarification and may be an indirect action of metformin on insulin sensitivity [61]. The effect of autophagy to this "islet protective effect" of metformin is unknown if this effect exists. AMPK holds potential as novel therapeutic agents in the metabolic field and several new tissueselective activators of AMPK candidates are in the pipeline of several pharmaceutical companies [62]. But there is required further exploration of the effects of these agents on autophagy. AMPK activity can be increased by long-acting fatty acid analogues and by this mechanism act to modify autophagy in diabetes [63].

\section{Conclusion}

The exact roles of autophagic regulation in case of T2DM have not yet been clarified. Most of the studies recommend that enhanced autophagy induced by insulin resistance may be a defensive tool against the dysfunction and enhanced death of pancreatic $\beta$-cells. Nowadays finding the effects of autophagy in cell survival or cell death in case of diabetes is an imperative area of research. Therefore, therapeutic agents with autophagy-enhancing activity, but without harmful effects on $\beta$-cells might assist as a novel class of promising pharmaceuticals for T2DM.

\section{Authors Contributions}

This work was carried out in collaboration between all authors. Authors MTI and MSU designed the study, wrote the protocol, managed the analyses of the study and prepared the draft of the manuscript. Authors KNL, MMI, SMSI, MTK, MFH and AAM managed the literature searches and also participated in manuscript preparation. Authors MSU and MSA reviewed the scientific contents of the manuscript. All the authors read and approved the final manuscript.

\section{Acknowledgements}

The authors wish to thank the anonymous reviewer(s)/editor(s) of this article for their constructive reviews. The authors are also grateful to the Department of Pharmacy, Southeast University, Dhaka, Bangladesh.

\section{Competing Interests}

The authors proclaim that they have no competing interests.

\section{References}

1. Klionsky DJ, Emr SD (2000) Autophagy as a regulated pathway of cellular degradation. Science 290: 1717-1721.

2. Lum JJ, Bauer DE, Kong M, Harris MH, Li C, et al. (2005) Growth factor regulation of autophagy and cell survival in the absence of apoptosis. Cell 120: 237-248.

3. Boya P, González-Polo RA, Casares N, Perfettini JL, Dessen P, et al. (2005) Inhibition of macroautophagy triggers apoptosis. Mol Cell Biol 25: 1025-1040.

4. Jung HS, Lee MS (2010) Role of autophagy in diabetes and mitochondria. Ann N Y Acad Sci 1201: 79-83.

5. Qu X, Zou Z, Sun Q, Luby-Phelps K, Cheng P, et al. (2007) Autophagy gene-dependent clearance of apoptotic cells during embryonic development. Cell 128: 931-946.

6. Komatsu M, Waguri S, Ueno T, Iwata J, Murata S, et al. (2005) Impairment of starvation- induced and constitutive autophagy in Atg7deficient mice. J Cell Biol 169: 425-434.

7. Hara T, Nakamura K, Matsui M, Yamamoto A, Nakahara Y, et al. (2006) Suppression of basal autophagy in neural cells causes neurodegenerative disease in mice. Nature 441: 885-889.

8. Nakai A, Yamaguchi O, Takeda T, Higuchi Y, Hikoso S, et al. (2007) The role of autophagy in cardiomyocytes in the basal state and in response to hemodynamic stress. Nat Med 13: 619-624.

9. Levine B, Kroemer G (2008) Autophagy in the pathogenesis of disease. Cell 132: 27-42.

10. Yorimitsu T, Nair U, Yang Z, Klionsky DJ (2006) Endoplasmic reticulum stress triggers autophagy. J Biol Chem 281: 30299-30304.

11. Blommaart EF, Luiken JJ, Blommaart PJ, van Woerkom GM, Meijer AJ (1995) Phosphorylation of ribosomal protein S6 is inhibitory for autophagy in isolated rat hepatocytes. J Biol Chem 270: 2320-2326.

12. Ashford TP, Porter KR (1962) Cytoplasmic components in hepatic cell lysosomes. J Cell Biol 12: 198-202.

13. Petersen KF, Dufour S, Befroy D, Garcia R, Shulman GI (2004) Impaired mitochondrial activity in the insulin-resistant offspring of patients with type 2 diabetes. N Engl J Med 350: 664-671.

14. Bernales S, Schuck S, Walter P (2007) ER-phagy: Selective autophagy of the endoplasmic reticulum. Autophagy 3: 285-287.

15. Uchizono Y, Alarcon C, Wicksteed BL, Marsh BJ, Rhodes CJ (2007) The balance between proinsulin biosynthesis and insulin secretion: Where can imbalance lead? Diabetes Obes Metab 9: 56-66. 
Citation: Islam MT, Uddin MS, Lucky KN, Islam MM, Saiful Islam SM, et al. (2017) Autophagic Dysfunction in Type 2 Diabetes Mellitus: Pathophysiology and Therapeutic Implications. J Diabeteas Metab 8: 742. doi:10.4172/2155-6156.1000742

Page 7 of 8

16. Deter RL, and de Duve C (1967) Influence of glucagon, an inducer of cellular autophagy, on some physical properties of rat liver lysosomes. J Cell Biol 33: 437-449.

17. Lee MS (2014) Role of islet B cell autophagy in the pathogenesis of diabetes. Trends Endocrinol Metab 25: 620-627.

18. Quan W, Hur KY, Lim Y, Oh SH, Lee JC, et al. (2012) Autophagy deficiency in beta cells leads to compromised unfolded protein response and progression from obesity to diabetes in mice. Diabetologia 55: 392403.

19. Li WW, Alexandre S, Cao X, Lee AS (1993) Transactivation of the grp78 promoter by Ca2+ depletion. J Biol Chem 268: 12003-12009.

20. Choi SE, Lee SM, Lee YJ, Li LJ, Lee SJ, et al. (2009) Protective role of autophagy in palmitateinduced INS-1 beta cell death. Endocrinology 150 : 126-134.

21. Bachar-Wikstrom E, et al. (2013) Stimulation of autophagy improves endoplasmic reticulum stress-induced diabetes. Diabetes 62: 1227-1237.

22. Bartolome A, Wikstrom JD, Ariav Y, Tirosh B, Kaiser N, et al. (2012) Autophagy plays a protective role in endoplasmic reticulum stressmediated pancreatic $b$ cell death. Autophagy 8: 1757-1768.

23. Takeshige K, Baba M, Tsuboi S, Noda T, Ohsumi Y (1992) Autophagy in yeast demonstrated with proteinase-deficient mutants and conditions for its induction. J Cell Biology 119: 301-301.

24. Orci L, Ravazzola, M, Amherdt M, Yanaihara C, Yanaihara N, et al. (1984) Insulin, not C-peptide, is present in crinophagic bodies of the pancreatic b-cell. J Cell Biol 98: 222-228.

25. Twig G, Elorza A, Molina AJ, Mohamed H, Wikstrom JD, et al. (2008) Fission and selective fusion govern mitochondrial segregation and elimination by autophagy. EMBO J 27: 433-446.

26. Komatsu M, Waguri S, Koike M, Sou YS, Ueno T, et al. (2007) Homeostatic levels of p62 control cytoplasmic inclusion body formation in autophagy-deficient mice. Cell 131: 1149-1163.

27. Chen Z-F, Li YB, Han JY, Yin JJ, Wang Y, et al. (2013) Liraglutide prevents high glucose level induced insulinoma cells apoptosis by targeting autophagy. Chin Med J (Engl) 126: 937-941.

28. Yusta B, Baggio LL, Estall JL, Koehler JA, Holland DP, et al. (2006) GLP-1 receptor activation improves beta cell function and survival following induction of endoplasmic reticulum stress. Cell Metab 4: 391-406.

29. Sharma S, Mells JE, Fu PP, Saxena NK, Anania FA (2011) GLP-1 analogs reduce hepatocyte steatosis and improve survival by enhancing the unfolded protein response and promoting macroautophagy. PLoS One 6: e25269.

30. Kaniuk NA, Kiraly M, Bates H, Vranic M, Volchuk A, et al. (2007) Ubiquitinated-protein aggregates form in pancreatic beta-cells during diabetes-induced oxidative stress and are regulated by autophagy. Diabetes 56: 930-939.

31. Scheuner D, Vander Mierde D, Song B, Flamez D, Creemers JW, et al. (2005) Control of mRNA translation preserves endoplasmic reticulum function in beta cells and maintains glucose homeostasis. Nat Med 11: 757-764.

32. Houck SA, Ren HY, Madden VJ, Bonner JN, Conlin MP, et al. (2014) Quality control autophagy degrades soluble ERAD-resistant conformers of the misfolded membrane protein GnRHR. Mol Cell 54: 166-179.

33. Tenemura M, Ohmura Y, Deguchi T, Machida T, Tsukamoto R, et al. (2012) Rapamycin causes upregulation of autophagy and impairs islets function both in vitro and in vivo. Am J Transplant 12: 102-114.

34. Masini M, Bugliani M, Lupi R, del Guerra S, Boggi U, et al. (2009) Autophagy in human type 2 diabetes pancreatic beta cells. Diabetologia 52: 1083-1086.

35. Park K, Verchere CB, (2001) Identification of a heparin binding domain in the N-terminal cleavage site of pro-islet amyloid polypeptide. J Biol Chem 276: 16611-16616.

36. Hotamisligil GS, Shargill NS, Spiegelman BM (1993) Adipose expression of tumor necrosis factor-a: direct role in obesity-linked insulin resistance. Science 259: 87-91.
37. Youm YH, Adijiang A, Vandanmagsar B, Burk D, Ravussin A, et al. (2011) Elimination of the NLRP3-ASC inflammasome protects against chronic obesity-induced pancreatic damage. Endocrinology 152: 4039-4045.

38. Westwell-Roper C, Dai DL, Soukhatcheva G, Potter KJ, van Rooijen N, et al. (2011) IL-1 blockade attenuates islet amyloid polypeptide-induced proinflammatory cytokine release and pancreatic islet graft dysfunction. J Immunol 187: 2755-2765.

39. Saitoh T, Fujita N, Jang MH, Uematsu S, Yang BG, et al. (2008) Loss of the autophagy protein Atg16L1 enhances endotoxin-induced IL-1beta production. Nature 456: 264-269.

40. Ozcan U, Cao Q, Yilmaz E, Lee AH, Iwakoshi NN, et al. (2004) Endoplasmic reticulum stress links obesity, insulin action, and type 2 diabetes. Science 306: 457-461.

41. Yang L, Li P, Fu S, Calay ES, Hotamisligil GS (2010) Defective hepatic autophagy in obesity promotes ER stress and causes insulin resistance. Cell Metab 11: 467-478.

42. Zhou L, Zhang J, Fang Q, Liu M, Liu X, et al. (2009) Autophagy-mediated insulin receptor down-regulation contributes to endoplasmic reticulum stress-induced insulin resistance. Mol Pharmacol 76: 596-603.

43. Liu HY, Han J, Cao SY, Hong T, Zhuo D, et al. (2009) Hepatic autophagy is suppressed in the presence of insulin resistance and hyperinsulinemia: Inhibition of FoxO1- dependent expression of key autophagy genes by insulin. J Biol Chem 284: 31484-31492.

44. Quan W, Lim YM, Lee MS (2012) Role of autophagy in diabetes and endoplasmic reticulum stress of pancreatic $\beta$-cells. Experi Mol Med 44: 81-88.

45. Weyer C, Bogardus C, Mott DM, Pratley RE (1999) The natural history of insulin secretory dysfunction and insulin resistance in the pathogenesis of type 2 diabetes mellitus. J Clin Invest 104: 787-794.

46. Kasuga $\mathrm{M}$ (2006) Insulin resistance and pancreatic beta cell failure. J Clin Invest 116: 1756-7160.

47. Ebato C, Uchida T, Arakawa M, Komatsu M, Ueno T, et al. (2008) Autophagy is important in islet homeostasis and compensatory increase of beta cell mass in response to high-fat diet. Cell Metab 8:325-332.

48. Jung HS, Chung KW, Won Kim J, Kim J, Komatsu M, et al. (2008) Loss of autophagy diminishes pancreatic beta cell mass and function with resultant hyperglycemia. Cell Metab 8: 318-324.

49. Kim KH, Jeong YT, Oh H, Kim SH, Cho JM, et al. (2013) Autophagy deficiency leads to protection from obesity and insulin resistance by inducing Fgf21 as a mitokine. Nat Med 19: 83-92.

50. Singh R, Xiang Y, Wang Y, Baikati K, Cuervo AM, et al. (2009) Autophagy regulates adipose mass and differentiation in mice. $\mathrm{J}$ Clin Invest 119:3329-3339.

51. Kume S, Yamahara K, Yasuda M, Maegawa H, Koya D (2014) Autophagy: emerging therapeutic target for diabetic nephropathy. Seminars Nephrol 34: 9-16.

52. Colman RJ, Anderson RM, Johnson SC, Kastman EK, Kosmatka KJ, et al. (2009) Caloric restriction delays disease onset and mortality in rhesus monkeys. Science 325: 201-204.

53. Fontana L, Partridge L, Longo VD (2010) Extending healthy life spanfrom yeast to humans. Science 328:321-326.

54. Cherry, Engelman RW, Wang BY, Kinjoh K, El-Badri NS, et al. (1998) Calorie restriction delays the crescentic glomerulonephritis of SCG/Kj mice. Proc Soc Exp Biol Med 218: 218-222.

55. Shapiro AM, Lakey JR, Ryan EA, Korbutt GS, Toth E, et al. (2003) Islet transplantation in seven patients with type 1 diabetes mellitus using a glucocorticoid-free immunosuppressive regimen. N Eng J Med 343: 230-238.

56. Newgard CB, An J, Bain JR, Muehlbauer MJ, Stevens RD, et al. (2009) A branched-chain amino acid-related metabolic signature that differentiates obese and lean humans and contributes to insulin resistance. Cell Metab 9: 311-326. 
Citation: Islam MT, Uddin MS, Lucky KN, Islam MM, Saiful Islam SM, et al. (2017) Autophagic Dysfunction in Type 2 Diabetes Mellitus: Pathophysiology and Therapeutic Implications. J Diabeteas Metab 8: 742. doi:10.4172/2155-6156.1000742

Page 8 of 8

57. Martinet W, Verheye S, De Meyer GR (2007) Everolimus-induced mTOR inhibition selectively depletes macrophages in atherosclerotic plaques by autophagy. Autophagy 3: 241-244.

58. Masini M, Bugliani M, Lupi R, Del Guerra S, Boggi U, et al. (2009) Autophagy in human type 2 diabetes pancreatic beta cells. Diabetologia 52: 1083-1086.

59. Kola B, Boscaro M, Rutter GA, Grossman AB, Korbonits M (2006) Expanding role of AMPK in endocrinology. Trends Endocrinol Metab 17: 205-215.

60. Kalender A, Selvaraj A, Kim SY, Gulati P, Brûlé S, et al. (2010) Metformin, independent of AMPK, inhibits mTORC1 in a rag GTPase-dependent manner. Cell Metab 11: 390-401.
61. Choi SH, Zhao ZS, Lee YJ, Kim SK, Kim DJ, et al. (2007) The different mechanisms of insulin sensitizers to prevent type 2 diabetes in OLETF rats. Diabetes Metab Res Rev 23: 411-418.

62. Zhou G, Sebhat IK, Zhang BB (2009) AMPK activators-potential therapeutics for metabolic and other diseases. Acta Physiol (Oxf) 196 $175-190$.

63. Za'tara G, Bar-Tana J, Kalderon B, Suter M, Morad E, et al. (2008) AMPK activation by long chain fatty acyl analogs. Biochem Pharmacol 76: 1263-1275. 